\title{
Commentary: The second cut is the deepest
}

\author{
Stephanie N. Nguyen, MD, ${ }^{a}$ David Blitzer, MD, ${ }^{a}$ \\ Shepard D. Weiner, MD, ${ }^{b}$ and \\ Hiroo Takayama, MD, $\mathrm{PhD}^{\mathrm{a}}$
}

The video clip by Sun and colleagues ${ }^{1}$ demonstrates an impressive degree of cavity obliteration with an extremely thick interventricular septum measuring $48 \mathrm{~mm}$. The patient had previously undergone transaortic septal myectomy to relieve left ventricular outflow tract (LVOT) obstruction at another institution with persistence of heart failure symptoms. A reoperative transapical myectomy was performed with significant improvement in left ventricular chamber size and diastolic function. This case poses at least 2 important questions.

First, how do we determine whether symptoms are secondary to LVOT obstruction or diastolic dysfunction? In reality, many patients suffer from a variable combination of both pathologies, and failure to recognize the latter may result in residual symptoms, even though transaortic septal myectomy is an excellent septal reduction therapy for relief of LVOT obstruction ${ }^{2,3}$ and can be performed with less than $1 \%$ mortality in experienced hypertrophic cardiomyopathy (HCM) centers. ${ }^{4}$ Of note, in a large, single-center series of 699 patients who underwent transaortic septal myectomy, $14.5 \%$ remained in class II and $4.5 \%$ in class III at mean follow-up of $6.2 \pm 3$ years. ${ }^{5}$ "Only" 81\% improved to New York Heart Association class I. Clearly, LVOT obstruction may not be the only problem at hand.

\footnotetext{
From the ${ }^{\mathrm{a}}$ Division of Cardiac, Thoracic and Vascular Surgery, Department of Surgery, and ${ }^{\mathrm{b}}$ Division of Cardiology, Department of Medicine, Hypertrophic Cardiomyopathy Center, Columbia University Medical Center/New York-Presbyterian, New York, NY.

Disclosures: The authors reported no conflicts of interest.

The Journal policy requires editors and reviewers to disclose conflicts of interest and to decline handling or reviewing manuscripts for which they may have a conflict of interest. The editors and reviewers of this article have no conflicts of interest.

Received for publication May 8, 2021; revisions received May 8, 2021; accepted for publication May 11, 2021; available ahead of print May 14, 2021.

Address for reprints: Hiroo Takayama, MD, $\mathrm{PhD}$, Columbia University Medical Center, 177 Fort Washington Ave, New York, NY 10032 (E-mail: ht2225@cumc. columbia.edu).

JTCVS Techniques 2021;8:73-4

2666-2507

Copyright (C) 2021 The Author(s). Published by Elsevier Inc. on behalf of The American Association for Thoracic Surgery. This is an open access article under the CC BY license (http://creativecommons.org/licenses/by/4.0/).

https://doi.org/10.1016/j.xjtc.2021.05.008
}

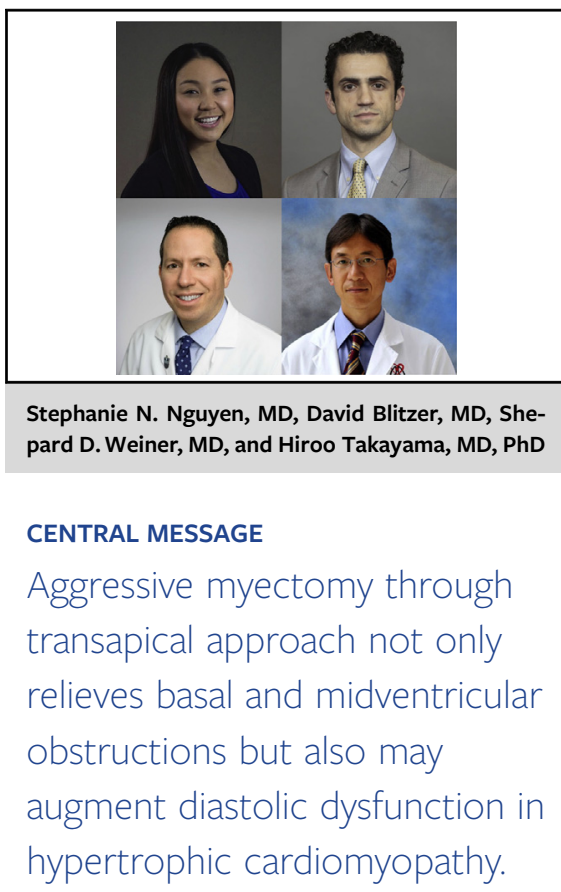

Second, does an aggressive myectomy relieve diastolic dysfunction? There is a clear relationship between diastolic dysfunction and heart failure in nonobstructive HCM, and this should be evaluated with echocardiography and invasive hemodynamic catheterization to identify this larger group of patients with HCM. The Mayo group has championed a transapical approach. Their combined transaortic and transapical approach has been shown to abolish any cavitary obstruction and augment left ventricular diastolic function with good short-term outcomes. ${ }^{6,7}$ This is important, as untreated midventricular obstruction not only leads to significant functional impairment but is also associated with reduced survival and greater risk of ventricular arrhythmias. ${ }^{8}$ Fortunately, complex multilevel septal hypertrophy occurs only $\sim 5 \%$ of patients with HCM. However, their recent case series showed a larger purpose of transapical myectomy. In their series of 113 patients with apical HCM who underwent transapical myectomy, $76 \%$ of patients reported an improvement in symptoms with superior survival to patients with HCM listed for heart transplantation. ${ }^{9}$ These promising results suggest that an aggressive myectomy does relieve diastolic dysfunction. The presented case is an excellent illustration of this approach. Seeing is believing.

This 24-year-old male patient might have received a heart transplantation had he been treated elsewhere. While our own institutional data of 41 patients with end-stage HCM managed with heart transplantation suggest it is a good 
option, ${ }^{10}$ transplant comes with costs. It may be time for $\mathrm{HCM}$ and heart failure experts to listen to the message of the Mayo group, "long-term survival (after transapical myectomy) appears superior to those listed for heart transplantation." 9

\section{References}

1. Sun D, Schaff HV, Nishimura RA. Reoperation for nonobstructive hypertrophic cardiomyopathy in a patient with extreme septal thickness. J Thorac Cardiovasc Surg Tech. 2021;8:71-2.

2. Writing Committee Members, Ommen SR, Mital S, Burke MA, Day SM, Deswal A, Elliott P, et al. 2020 AHA/ACC guideline for the diagnosis and treatment of patients with hypertrophic cardiomyopathy: a report of the American College of Cardiology/American Heart Association Joint Committee on Clinical Practice Guidelines. J Thorac Cardiovasc Surg. 2020;142:e533-7.

3. Elliott PM, Anastasakis A, Borger MA, Borggrefe M, Cecchi F, Charron P, et al; Authors/Task Force members. 2014 ESC Guidelines on diagnosis and management of hypertrophic cardiomyopathy: the task force for the diagnosis and management of hypertrophic cardiomyopathy of the European Society of Cardiology (ESC). Eur Heart J. 2014;35:2733-79.
4. Liebregts M, Vriesendorp PA, Mahmoodi BK, Schinkel AF, Michels M, ten Berg JM. A systematic review and meta-analysis of long-term outcomes after septal reduction therapy in patients with hypertrophic cardiomyopathy. JACC Heart Fail. 2015;3:896-905.

5. Desai MY, Bhonsale A, Smedira NG, Naji P, Thamilarasan M, Lytle BW, et al. Predictors of long-term outcomes in symptomatic hypertrophic obstructive cardiomyopathy patients undergoing surgical relief of left ventricular outflow tract obstruction. Circulation. 2013;128:209-16.

6. Said SM, Schaff HV, Abel MD, Dearani JA. Transapical approach for apical myectomy and relief of midventricular obstruction in hypertrophic cardiomyopathy. J Card Surg. 2012;27:443-8.

7. Hang D, Schaff HV, Ommen SR, Dearani JA, Nishimura RA. Combined transaortic and transapical approach to septal myectomy in patients with complex hypertrophic cardiomyopathy. J Thorac Cardiovasc Surg. 2018;155:2096-102.

8. Minami Y, Kajimoto K, Terajima Y, Yashiro B, Okayama D, Haruki S, et al. Clinical implications of midventricular obstruction in patients with hypertrophic cardiomyopathy. J Am Coll Cardiol. 2011;57:2346-55.

9. Nguyen A, Schaff HV, Nishimura RA, Geske JB, Dearani JA, King KS, et al. Apical myectomy for patients with hypertrophic cardiomyopathy and advanced heart failure. J Thorac Cardiovasc Surg. April 5, 2019 [Epub ahead of print].

10. Kato TS, Takayama H, Yoshizawa S, Marboe C, Schulze PC, Farr M, et al. Cardiac transplantation in patients with hypertrophic cardiomyopathy. Am J Cardiol. 2012;110:568-74. 